Joanna Szczepaniak-Sienniak

Uniwersytet Ekonomiczny we Wrocławiu

\title{
Potencjalne kierunki zmian w zakresie wychowania przedszkolnego w świetle oczekiwań rodzin
}

DOI: $10.19195 / 1643-0328.24 .9$

Słowa kluczowe: instytucjonalne i alternatywne formy wychowania przedszkolnego, przedszkola publiczne, oczekiwania rodzin

\section{Wprowadzenie}

W Polsce, zgodnie z ustawą o systemie oświaty ${ }^{1}$, formy wychowania przedszkolnego obejmują przedszkole, zespół wychowania przedszkolnego, oddział przedszkolny w szkole podstawowej, punkt przedszkolny. $\mathrm{W}$ niniejszym artykule mowa będzie także o innych - potencjalnych - formach instytucjonalnego wychowania przedszkolnego, niefunkcjonujących w aktualnie obowiązującym ustawodawstwie oświatowym, ale uwzględnionych $\mathrm{w}$ analizie jako alternatywne wobec instytucji przedszkolnych sposoby wsparcia.

W licznych badaniach naukowych funkcjonowanie instytucjonalnej opieki nad małymi dziećmi ( $w$ wieku przedszkolnym, ale też do lat 3 ) ukazywane jest w kontekście różnych korzyści o społecznym, demograficznym lub gospodarczym charakterze. Przy tym istotne jest rozróżnienie na dostępność i jakość funkcjonowania instytucji publicznych (finansowanych i zapewnianych przez państwo lub samorządy) oraz niepublicznych (oferowanych w sektorze prywatnym i pozarządowym) ${ }^{2}$, a także uwzględnienie perspektywy krótkoi długookresowej w analizie danych skutków ${ }^{3}$.

1 Ustawa o systemie oświaty, Dz.U. z 2016 r. poz. 1943 — akt jednolity.

${ }^{2}$ W Polsce, zgodnie z ustawą o systemie oświaty, instytucje wychowania przedszkolnego mogą być prowadzone przez gminy, przedsiębiorstwa, organizacje pozarządowe, osoby fizyczne prowadzące odpowiednią działalność gospodarczą, uczelnie wyższe.

3 Por. W.S. Barnett, Effectiveness of early educational intervention, „Science” 333(6045), 2011, s. 975-978; A. Kurowska, K. Szczupak, Zmiany w dostępie do usług opieki nad dzieckiem poniżej trzech lat w polskich gminach i popyt na te usługi, „Prace Naukowe Uniwersytetu Ekonomicznego we Wrocławiu” nr 456, Wrocław 2016, s. 180-191; D. Moroń, Zmiany w zakresie instytucjonalnej opieki nad dziećmi do lat trzech w Polsce, „Prace Naukowe Uniwersytetu Ekonomicznego we Wrocławiu” nr 239, Wrocław 2011, s. 168. 
Korzystanie przez dzieci z wysokiej jakości usług wychowania przedszkolnego (realizowanych m.in. w przedszkolach) wpływa pozytywnie na ich rozwój intelektualny i emocjonalny. $Z$ badań naukowych wynika na przykład, że dzieci, które chodziły do przedszkola lub korzystały z innych form wysokiej jakości usług opiekuńczych od wieku przynajmniej 3 lat miały lepsze wyniki w nauce - rzadziej musiały powtarzać klasę lub przenosić się do szkół specjalnych ${ }^{4}$. Inne badania pokazują pozytywne skutki uczęszczania do przedszkola dzieci ze środowisk zagrożonych wykluczeniem społecznym lub z ubogich rodzin (szybszy rozwój intelektualny, mniej problemów wychowawczych w szkole, a następnie mniejsza skłonność wśród tych dzieci do angażowania się w działalność przestępczą, poprawa sytuacji materialnej w rodzinie - dzięki możliwości podjęcia pracy przez matki, lepszy stan zdrowia niż rówieśników — dzięki stałej kontroli stanu zdrowia przez instytucje opiekuńcze $)^{5}$.

W Polsce $\mathrm{w}$ ostatnich latach dokonywano wielu zmian w dziedzinie wychowania przedszkolnego; ważniejsze $\mathrm{z}$ nich to:

— od 2008 r. umożliwiono tworzenie tzw. innych form wychowania przedszkolnego, tj. zespołów wychowania przedszkolnego, punktów przedszkolnych, oddziałów przedszkolnych;

— od września 2011 r. wprowadzono obowiązek objęcia wychowaniem przedszkolnym wszystkich pięciolatków (jednocześnie obowiązek szkolny został obniżony z 7 . do 6. roku życia);

— od września 2013 r. samorządy otrzymują dotację celową na rozwój instytucji wychowania przedszkolnego oraz obniżenie opłat dla rodziców za pobyt dziecka w przedszkolu — jeśli dziecko przebywa w nim dłużej niż czas ustawowo bezpłatny (ustala go gmina, przy czym musi wynosić minimum 5 godzin), to każda kolejna godzina nie może kosztować więcej niż $1 \mathrm{zł}$

- wprowadzono ustawowe kryteria rekrutacji zapewniające pierwszeństwo w dostępie do placówki przedszkolnej w następujących wypadkach: wielodzietność; niepełnosprawność dziecka, rodzica lub jednego z nich lub rodzeństwa; samotne wychowanie dziecka; wychowywanie dziecka w pieczy zastępczej;

— od 1 września 2017 r. zniesiono obowiązek szkolny od 6. roku życia (obowiązek taki wprowadzono od 7. roku życia), co oznacza, że dzieci w tym wieku mogą pozostać w przedszkolach; prawo do wychowania przedszkolnego mają także dzieci w wieku 3-5 lat.

Warto przypomnieć, że jeszcze w 2006 r. Polska znajdowała się wśród krajów o najniższym wskaźniku wychowania przedszkolnego (w roku szkolnym 2005/2006 wskaźnik u p o w s z e c h n i e n i a p r z e d s z k o li, tj. współczynnik skolaryzacji dzieci w wieku 3-5 lat, wynosił zaledwie $41 \%$ przy oczekiwanej wartości tego wskaźnika $90 \%$

4 Por. W.S. Barnett, op. cit.

5 Cyt. za: D. Szelewa, Usługi opiekuńcze dla małych dzieci: główne argumenty za rozszerzeniem dostępu do publicznych ustug opieki nad dzieckiem, „Warszawskie Debaty o Polityce Społecznej”, Warszawa 2011, s. 15-21. Por. W.S. Barnett, op. cit.

6 Ustawa o systemie oświaty..., art. 20c. 
w $2020 \mathrm{roku}^{7}$ ). Od tego czasu upowszechnienie wychowania przedszkolnego w Polsce istotnie wzrosło (do $84,1 \%$ w $2015 \mathrm{r}^{8}$ ).

Jednocześnie na podstawie różnych obserwacji ${ }^{9}$ można stwierdzić, że - po pierwsze - oprócz instytucji przedszkolnych (przedszkoli, oddziałów przedszkolnych itp.) przydatnym wsparciem $\mathrm{w}$ wychowaniu dziecka $\mathrm{w}$ wieku przedszkolnym mogą być także inne instytucje i usługi w tym zakresie. Po drugie okazuje się, że funkcjonowanie publicznych przedszkoli nie zawsze jest zgodne z podstawowymi wymogami instytucjonalno-prawnymi oraz oczekiwaniami rodzin.

W związku z tym wyodrębnione zostały dwa problemy badawcze, wyznaczające treść niniejszego artykułu: 1 . Czy rodzice dzieci w wieku przedszkolnym oczekują innych niż instytucje przedszkolne form wsparcia w zakresie wychowania przedszkolnego? 2. Jakie są główne zastrzeżenia i oczekiwania rodzin odnośnie do jakości wychowania przedszkolnego w publicznych przedszkolach? Problemy te były asumptem do przeprowadzenia analizy potencjalnych oczekiwań rodzin dotyczących form i jakości wsparcia $\mathrm{w}$ wychowywaniu dzieci $\mathrm{w}$ wieku przedszkolnym na przykładzie opinii wybranych grup wrocławskich rodzin (z dziećmi uczęszczającymi do publicznych przedszkoli). Analiza ta przeprowadzona została we Wrocławiu w latach 2015 i $2016^{10}$ na podstawie badania ilościowego wykonanego techniką ankietową oraz badania jakościowego - zogniskowanego wywiadu grupowego (Focus Group Interview - FGI). Wyniki tych badań pozwalają na określenie potencjalnych działań i kierunków zmian w zakresie wychowania przedszkolnego, co też jest celem niniejszego artykułu. Należy mieć na uwadze, że znamienną cechą Wrocławia jest występowanie wysokiego, w porównaniu do innych miast Polski, współczynnika skolaryzacji dzieci w wieku 3-5 lat - 93,6\% w 2015 r. ${ }^{11}$ (dla przypomnienia: w Polsce w tym samym czasie wskaźnik ten wyniósł 84,1\%).

7 Strategia Rozwoju Kapitału Ludzkiego 2020, s. 70, https://www.mpips.gov.pl/praca/strategie-i-dokumenty-programowe/strategia-rozwoju-kapitalu-ludzkiego-srkl---projekt-z-31072012-r/ (dostęp: 6 kwietnia 2017).

${ }^{8}$ Por. Sprawozdanie z realizacji „Strategii Rozwoju Kapitału Ludzkiego 2020” za 2015 rok, s. 10, https:// www.mpips.gov.pl/praca/strategie-i-dokumenty-programowe/strategia-rozwoju-kapitalu-ludzkiego-srkl--projekt-z-31072012-r/ (dostęp: 6 kwietnia 2017).

9 Por. Informacja o wynikach kontroli wychowania przedszkolnego, Raport NIK (KNO-4101-0100/2010), Warszawa 2011; Finansowanie przez gminy przedszkoli publicznych i niepublicznych oraz wykonywanie przez te placówki niektórych zadań w zakresie kształcenia, wychowania i opieki, Raport NIK (LGD-4101-009/2013), Warszawa 2014; Families in the economic crisis: Changes in policy measures in the $E U$, Publications Office of the European Union, Eurofound, Luxembourg 2015, http://www.euro.centre.org/ data/1454079403_50470.pdf (dostęp: 30 czerwca 2017).

10 W ramach projektu Partycypacyjna polityka rodzinna miasta Wrocław oraz programu Obywatele dla Demokracji, realizowanego w partnerstwie z Gminą Wrocław, finansowanego ze środków Mechanizmu Finansowego Europejskiego Obszaru Gospodarczego (funduszy EOG). Więcej o projekcie: Participatory family policy of the city of Wrocław, http://eeagrants.org/project-portal/project/PL05-0492 (dostęp: 26 lipca 2016); http:// frip.org.pl/projekty/biezace/13-partycypacyjna-polityka-rodzinna-miasta-wroclaw (dostęp: 26 lipca 2016).

11 Bank Danych Lokalnych GUS (https://bdl.stat.gov.pl), obliczenia własne (według stanu w dniu 30 listopada 2015 r.) (dostęp: 30 czerwca 2017). 


\section{Metodyka badań}

Zasadniczą część analizy stanowiło badanie ilościowe z zastosowaniem techniki ankietowej, które uzupełnione zostało badaniem jakościowym — zogniskowanym wywiadem fokusowym.

Badanie ilościowe zostało zrealizowane na celowej próbie respondentów wybranej spośród mieszkańców Wrocławia mających dzieci w wieku przedszkolnym $\left(2,5-5\right.$ lat $\left.^{12}\right)$ uczęszczające do przedszkola publicznego. Zastosowanie doboru celowego w opisywanym wypadku to rozwiązanie optymalne ze względu na znacznie ograniczone możliwości wylosowania próby reprezentatywnej, odpowiadającej kluczowym założeniom badawczym. Ponadto omawiane badanie ma charakter eksploracyjny, a jego celem jest zidentyfikowanie problemów, które mogą szerzej występować w rzeczywistości społecznej, warto je zatem uwzględnić w diagnozie potrzeb i oczekiwań rodzin oraz kształtowaniu odpowiedniej polityki w danym obszarze.

Badanie ankietowe prowadzone było w okresie od kwietnia 2015 do kwietnia $2016 \mathrm{r}$. W celu zwiększenia zwrotności ankiet zastosowana została zarówno forma tradycyjna (PAPI - Paper and Pencil Interview), jak i ankieta on-line (CAWI - Computer-Assisted Web Interview). Ankiety tradycyjne, przeznaczone do osobistego wypełnienia przez respondentów, udostępnione były w bibliotekach miejskich, publicznych przedszkolach, na piknikach miejskich oraz w ośrodkach pomocy społecznej. Informacje o ankiecie on-line, $\mathrm{w}$ tym możliwościach i warunkach uczestniczenia w badaniu, zamieszczone były na stronie internetowej i koncie Facebook Fundacji Rodzina i Przedsiębiorczośćc ${ }^{13}$ oraz na stronie Gminy Wrocław ${ }^{14}$, a także upowszechniane wśród organizacji współpracujących z tą fundacją, w tym głównie wśród członków Związku Dużych Rodzin Trzy Plus.

W badaniu ankietowym łącznie udział wzięło prawie 1000 osób, z czego analizie poddano 629 (około 75\%) ankiet - odpowiedzi respondentów, którzy spełnili kryterium doboru próby, a więc mieli co najmniej jedno dziecko w wieku 2,5-5 lat uczęszczające do publicznego przedszkola oraz wypełnili ankietę w sposób rzetelny i spójny.

Wśród badanych $81 \%$ stanowiły kobiety, a $19 \%$ mężczyźni (w badaniu z zastosowaniem ankiety tradycyjnej, np. na piknikach rodzinnych, można było zaobserwować, że nawet $\mathrm{w}$ wypadku, gdy bezpośrednio uczestniczyło w nim oboje rodziców, kwestionariusz wypełniała najczęściej matka). Były to przede wszystkim osoby w wieku 30-34 lata (33\%) i 35-39 lat (31\%), a także w wieku 40-44 (17\%). Osoby młodsze, w wieku 25-29 lat, stanowily $12 \%$, pozostali (2\%) to rodzice w wieku $18-24$ lata.

W badaniu dominowały rodziny wielodzietne, tj. $\mathrm{z}$ trojgiem dzieci (34\%), z czworgiem i więcej dzieci (7\%), co wynikało najprawdopodobniej z tego, że informacja o badaniu rozpowszechniana była przede wszystkim między członkami Związku Dużych

12 W okresie, w którym realizowane było badanie, dzieci sześcioletnie objęte były obowiązkiem szkolnym, stąd przyjęta w badaniu granica wieku przedszkolnego: 2,5-5 lat.

13 Koordynatora projektu Partycypacyjna polityka rodzinna miasta Wrocław.

14 Partnera projektu Partycypacyjna polityka rodzinna miasta Wrocław. 
Rodzin Trzy Plus. Następną stosunkowo liczną grupą były rodziny z dwojgiem dzieci (29\%) oraz z jednym dzieckiem (30\%).

Uczestniczący w badaniu mieli najczęściej wykształcenie wyższe (74\%). Większość respondentów (65\%) to osoby pracujące w pełnym wymiarze godzin, a następnie osoby pracujące na własny rachunek (prowadzące działalność gospodarczą $-13 \%)^{15}$. Deklarowany przez respondentów dochód na rodzinę (głównie z pracy zarobkowej) był różny; najwięcej osób (29\%) wskazało, że jest on wyższy niż 5000 zł, najmniej (6\%) - że nie przekracza $1000 \mathrm{zł}$.

Należy w tym miejscu podkreślić, że niektóre podgrupy są na tyle mało liczne, że uzyskane dla nich wyniki, zaprezentowane w dalszej części, należy traktować ze szczególną ostrożnością. Dotyczy to przede wszystkim rodzin z więcej niż czworgiem dzieci oraz osób pracujących dorywczo lub w wymiarze przekraczającym jeden etat.

Struktura i cechy próby oznaczają, że uzyskanych wyników nie można uogólniać na populację Wrocławia ani tym bardziej całej Polski. Ze względu na wielkość próby oraz sposób doboru respondentów uzyskane wyniki, chociaż niereprezentatywne dla wskazanych populacji, pozwalają jednak opisać potencjalne oczekiwania badanych rodzin.

W kwestionariuszu ankiety zawarto pytania dotyczące oczekiwań odnośnie do form wsparcia wychowania dziecka $\mathrm{w}$ wieku przedszkolnym, a także zastrzeżeń i oczekiwań dotyczących funkcjonowania przedszkoli (pytania te przedstawione zostaną przy omówieniu wyników badania ankietowego).

Drugim etapem badań empirycznych, mającym na celu pogłębienie wiedzy o oczekiwaniach badanych rodzin dotyczących wychowania przedszkolnego, wynikających $\mathrm{z}$ badania ankietowego, był zogniskowany wywiad grupowy (FGI). Uczestnikami tego wywiadu było sześć osób, w tym pięć kobiet i jeden mężczyzna, mających co najmniej jedno dziecko $\mathrm{w}$ wieku przedszkolnym uczęszczające do publicznego przedszkola. Rekrutacja uczestników badania odbywała się za pomocą ogłoszenia udostępnionego w Internecie (na stronie i koncie Facebook Fundacji Rodzina i Przedsiębiorczość). Do badania zaproszono pierwszych zgłoszonych chętnych (według kolejności wpływu zgłoszeń), którzy spełnili kryterium doboru próby.

\section{Wyniki badania ankietowego}

Celem zdiagnozowania oczekiwań badanych rodzin, dotyczących wychowania przedszkolnego ankietowanym zadano pytanie: Co jest/byłoby dla Pani/Pana największym ułatwieniem przy wychowaniu dziecka $\mathrm{w}$ wieku przedszkolnym? Respondenci zostali poproszeni o ponumerowanie odpowiedzi według ważności (od 1 - najważniejsze do 6 - najmniej ważne). Wśród odpowiedzi mieli do wyboru następujące opcje: swobodny dostęp do przedszkola (np. bliskość lokalizacji, łatwo dostępne miejsca w przedszkolu),

15 Odsetek osób pracujących na własny rachunek był bardzo zbliżony, niezależnie od płci respondenta. Odsetek prowadzących działalność gospodarczą był jednak wyższy wśród kobiet (prawie 17\%) niż wśród mężczyzn (niecałe 11\%). 
niska opłata za przedszkole oraz dzienny opiekun i niania, a także pomoc babci/dziadka lub innej osoby z rodziny (nieodpłatnie) i możliwość sprawowania opieki osobiście ( $w$ połączeniu ze świadczeniem pieniężnym związanym $\mathrm{z}$ brakiem możliwości podjęcia pracy z powodu tej opieki). W badaniu tym zapytano także o wysokość pożądanego świadczenia za opiekę osobistą. Założono bowiem, że informacja o oczekiwaniach rodzin w tym względzie może być bardzo interesująca w kontekście dyskusji nad formami i wysokością wsparcia finansowego dla rodzin z tytułu wychowywania dziecka/dzieci, która rozgorzała w związku z zapowiadanym w okresie tego badania programem Rodzina 500 Plus $^{16}$.

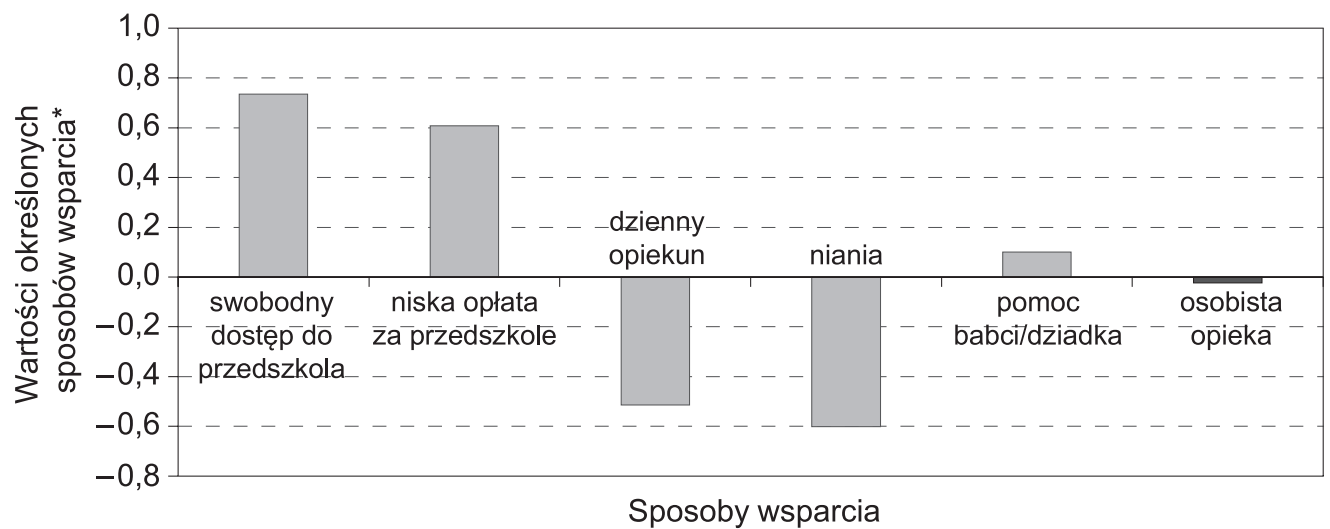

Rycina 1. Oczekiwania rodzin odnośnie do sposobów wsparcia w zakresie wychowania przedszkolnego i potencjalnych rozwiązań

* im wyższa wartość, tym dana forma wsparcia ważniejsza (skala: od -1 do 1; wartości powyżej 0 ważne, poniżej 0 nieważne).

Źródło: Wyniki badania ankietowego, opracowanie własne.

Usługi dziennego opiekuna i niani to formy opieki instytucjonalnej (pozarodzinnej, realizowanej w formie regulowanych ustawowo usług opieki indywidualnej) adresowane do dzieci w wieku do lat $3^{17}$. Zostały uwzględnione w omawianym badaniu jako alterna-

16 Program Rodzina 500 Plus jest systemem wsparcia rodzin z dziećmi, zwłaszcza rodzin wielodzietnych, funkcjonującym od kwietnia 2016 r. Świadczenie wychowawcze, w wysokości 500 zł, jest wypłacane rodzicom, opiekunom prawnym lub opiekunom faktycznym na każde dziecko do momentu osiągnięcia przez nie 18 lat. W wypadku ubiegania się o świadczenie na pierwsze dziecko obowiązuje kryterium dochodowe $800 \mathrm{zł}$ (jeśli dziecko jest niepełnosprawne, kryterium jest zwiększone do $1200 \mathrm{zł}$ ), na drugie i kolejne dziecko można się ubiegać o świadczenie niezależnie od wysokości dochodów. Zob. ustawa z dnia 11 lutego 2016 r. o pomocy państwa w wychowywaniu dzieci, Dz.U. z 2016 r. poz. 195.

17 Zgodnie z ustawą o opiece nad dzieckiem do lat 3 (Dz.U. z 2016 r. poz. 157 - akt jednolity). Wedle aktualnych regulacji dzienny opiekun sprawuje opiekę nad maksymalnie pięciorgiem dzieci, a w wypadku gdy w grupie znajduje się dziecko, które nie ukończyło pierwszego roku życia, jest niepełnosprawne lub wymaga szczególnej opieki, maksymalnie nad trojgiem dzieci (art. 38.1.). Natomiast nianią jest osoba fizyczna sprawująca opiekę nad dziećmi na podstawie umowy o świadczenie usług; sprawuje opiekę nad dziećmi w wieku od ukończenia 20. tygodnia życia (art. 50.1.). 
tywne - przykładowe - wobec przedszkoli (w ankiecie podkreślono, że chodzi o usługi podobne do funkcjonujących wobec dzieci do lat 3), by określić, czy rodzice w ogóle oczekują innych niż przedszkola form wychowania przedszkolnego, poza rodziną. Założono, że skłonienie respondentów do porównania przedszkoli z tymi właśnie usługami będzie zasadne ze względu na to, iż potencjalnie mogli z nich korzystać w przeszłości, gdy ich dzieci były młodsze, i z tego powodu są im znane. Należy też zauważyć, że są to zgoła inne niż w przedszkolach formy usług - bo świadczone w warunkach domowych. Tym bardziej nie można wykluczyć, że rodzice dzieci starszych niż 3 lata (w wieku przedszkolnym) nie preferowaliby tego typu wsparcia.

Uzyskane wyniki zostały zakodowane następująco: przypisano wartości +1 odpowiedziom 1 i 2, wartość -1 odpowiedziom 6 i 7, natomiast pozostałym odpowiedziom ( 3,4 oraz 5) wartość 0.

$\mathrm{Z}$ badania ankietowego wynika, że w badanej populacji rodziców dominują przede wszystkim oczekiwania dotyczące swobodnego dostępu do przedszkola (ryc. 1) przy przeciętnej, miesięcznej opłacie około 250 zł (ryc. 3) jako rozwiązania ułatwiającego wychowywanie dziecka w wieku przedszkolnym. Respondenci nie wskazali natomiast innych, zasugerowanych jako potencjalne instytucji wychowania przedszkolnego, takich jak dzienny opiekun czy niania. Z badań tych wynikać może także, że rodziny raczej nie zamieniłyby przedszkola na opiekę osobistą (nawet w połączeniu ze świadczeniem pieniężnym), ale uwzględniają pomoc babci/dziadka.

Nieco inne wyniki uzyskano, biorąc pod uwagę liczbę dzieci w rodzinie. Ankietowani z trojgiem, a zwłaszcza czworgiem i więcej dzieci, oprócz przedszkola stosunkowo często wskazali także osobistą opiekę jako jedną z najbardziej preferowanych form wychowania dziecka w wieku przedszkolnym (ryc. 2).

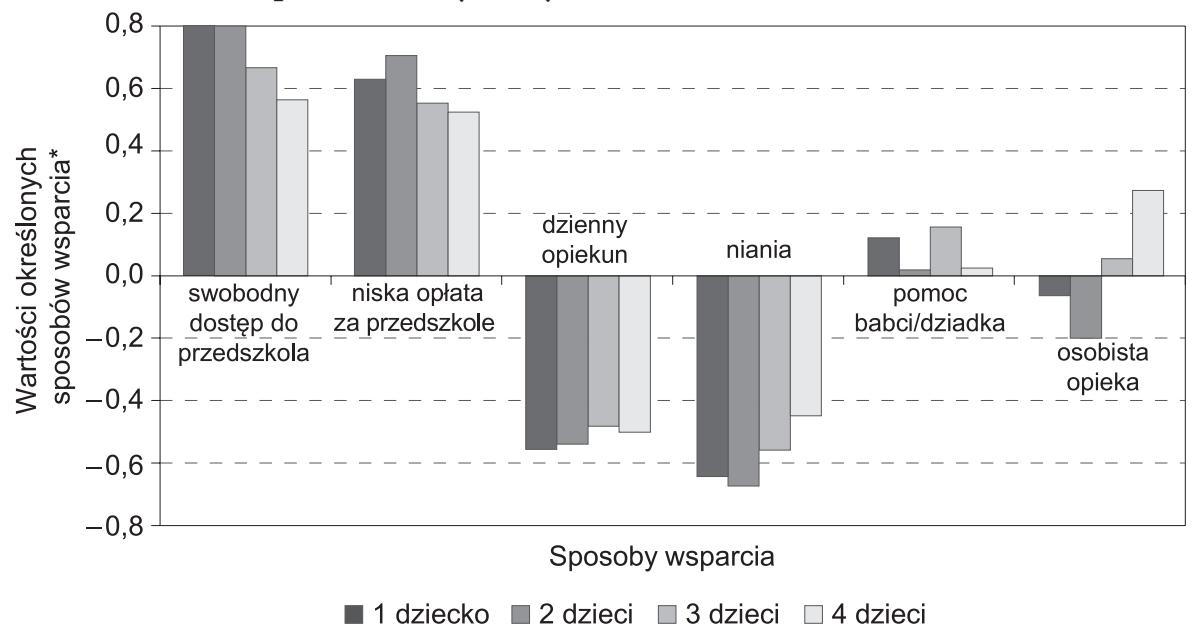

Rycina 2. Oczekiwania rodzin odnośnie do sposobów wsparcia w zakresie wychowania przedszkolnego, według liczby dzieci

* im wyższa wartość, tym dana forma wsparcia ważniejsza (skala: od -1 do 1; wartości powyżej 0 ważne, poniżej 0 nieważne).

Źródło: Wyniki badania ankietowego, opracowanie własne. 
Maksymalna średnia wysokość miesięcznej opłaty za przedszkole (za jedno dziecko) akceptowalnej przez badanych rodziców (ryc. 3) wynosi 247 zł. Im więcej dzieci $\mathrm{w}$ rodzinie, tym wysokość tej opłaty jest niższa — od około 300 zł dla rodziny z jednym dzieckiem do 175 zł (i mniej) dla rodziny z pięciorgiem dzieci (i więcej).

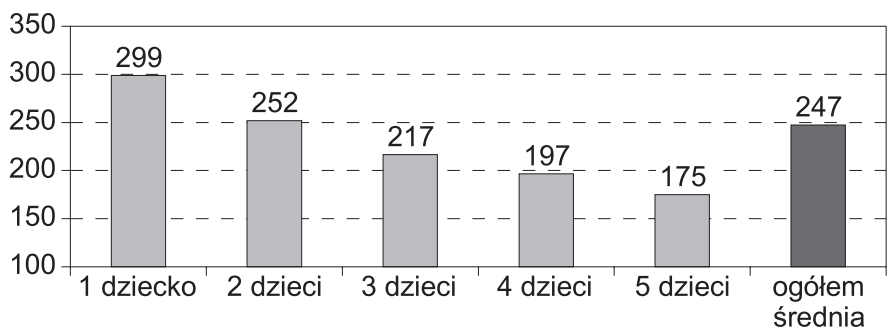

Rycina 3. Maksymalna średnia wysokość miesięcznej opłaty za przedszkole, akceptowalnej przez rodziny, według liczby dzieci (w zł)

Źródło: Wyniki badania ankietowego, opracowanie własne.

Z kolei przeciętna wysokość oczekiwanego miesięcznego świadczenia za osobiste wychowywanie dziecka/dzieci w wieku przedszkolnym - u badanych rodzin $\mathrm{z}$ trojgiem i więcej dzieci, jako tych, wśród których stosunkowo często oczekiwane jest tego typu rozwiązanie - wyniosła 1428 zł (ryc. 4). Co ciekawe, im więcej dzieci w rodzinie, tym pożądana wysokość omawianego świadczenia jest niższa. Może to być związane z tym, że rodziny wielodzietne (z trojgiem i więcej dzieci) uwzględniły możliwość otrzymywania też innych świadczeń pieniężnych $\mathrm{z}$ tytułu wychowania dziecka $\mathrm{w}$ rodzinie wielodzietnej, między innymi świadczeń rodzinnych czy też świadczenia wychowawczego w ramach programu Rodzina 500 Plus.

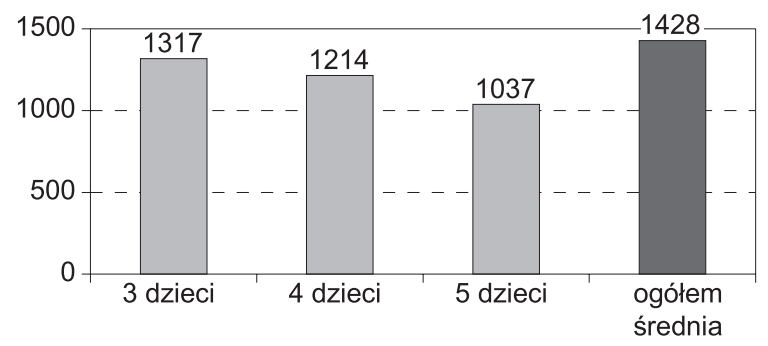

Rycina 4. Przeciętna wysokość miesięcznego pożądanego świadczenia za osobiste wychowywanie dziecka w wieku przedszkolnym, według liczby dzieci w rodzinie (w zł)

Źródło: Wyniki badania ankietowego, opracowanie własne.

W tym kontekście interesująca jest też ta część badania ankietowego, w której respondenci zostali zapytani, czy oczekują comiesięcznego świadczenia pieniężnego na dziecko, niezależnie od korzystania $\mathrm{z}$ innych form wsparcia. Większość badanych, tj. $94 \%$, odpowiedziało — jak można było się spodziewać - że tak. Co ciekawe, niezależnie od dochodu w rodzinie oczekiwana wysokość takiego świadczenia nie różniła się znacząco (w granicach od około 600-700 zł), a mediana wszystkich wskazań to $500 \mathrm{zł}$ 
(ryc. 5); kwota ta była najprawdopodobniej efektem tego, że badanie było realizowane w okresie prezydenckiej kampanii wyborczej i zapowiadania programu Rodzina 500 Plus. Ankietowane rodziny z trojgiem i więcej dzieci najczęściej wydałyby takie wsparcie na osobiste sprawowanie opieki (nie na przedszkole czy inną instytucję przedszkolną ani też nie na pomoc babci/dziadka).

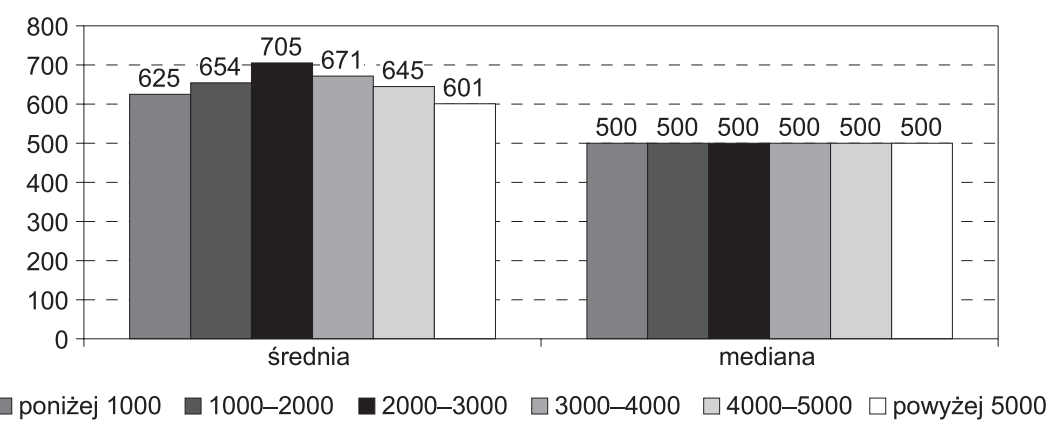

Rycina 5. Wysokość oczekiwanego comiesięcznego świadczenia na dziecko (w zł), według dochodu w rodzinie

Źródło: Wyniki badania ankietowego, opracowanie własne.

Interesujące są też te wyniki omawianego badania, które dotyczą oczekiwań rodzin wobec form wychowania przedszkolnego w zależności od poziomu wykształcenia, statusu na rynku pracy oraz poziomu dochodu $\mathrm{w}$ rodzinie.

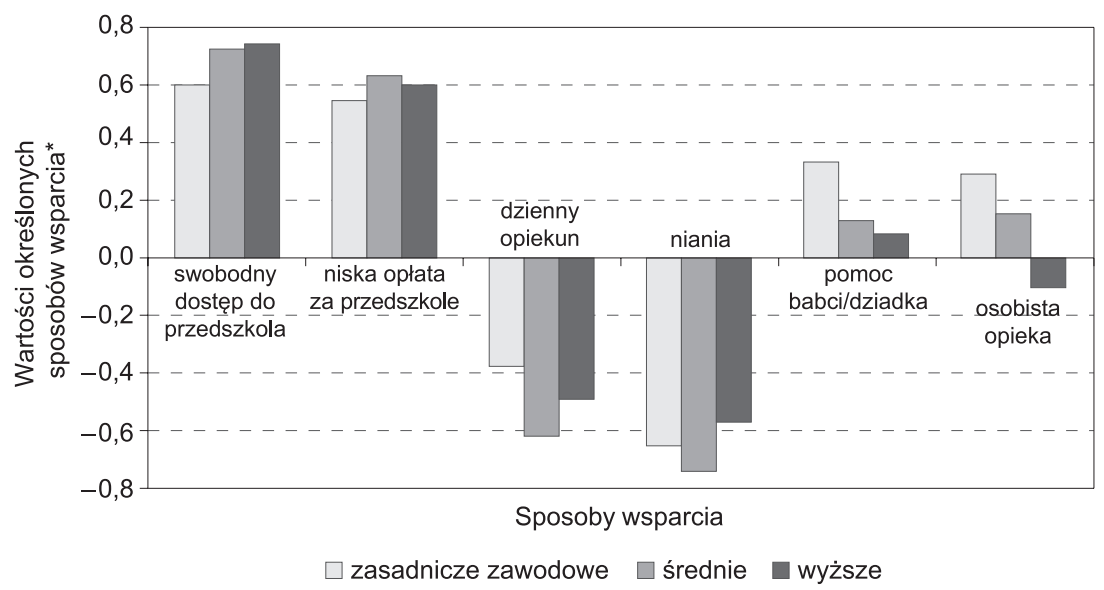

Rycina 6. Oczekiwania rodzin odnośnie do sposobów wsparcia w zakresie wychowania przedszkolnego, według wykształcenia respondenta

* im wyższa wartość, tym dana forma wsparcia ważniejsza (skala: od -1 do 1; wartości powyżej 0 ważne, poniżej 0 nieważne).

Źródło: Wyniki badania ankietowego, opracowanie własne.

W tym wypadku warto zauważyć, że osobista opieka nad dzieckiem lub pomoc babci/ dziadka to wsparcie istotne przede wszystkim dla rodzin z wykształceniem zasadniczym 
zawodowym. Respondenci z wykształceniem średnim i wyższym dopuszczają pomoc babci/dziadka lub innej osoby w rodzinie znacznie rzadziej, a $z$ wykształceniem wyższym raczej nie przewidują osobistego wychowywania dziecka w wieku przedszkolnym.

Ważny może być także status rodzica/rodziców na rynku pracy. Omawiane badanie pokazuje na przykład, że osoby pracujące ponadwymiarowo (więcej niż 8 godzin dziennie) w ogóle nie uwzględniają osobistego wychowywania dziecka w wieku przedszkolnym, za to ważna jest dla nich pomoc babci/dziadka. Z kolei osoby pracujące dorywczo dopuszczają, jako jedyna grupa, osobistą opiekę jako dodatkową/alternatywną formę wychowania dziecka w wieku przedszkolnym (ryc. 7).

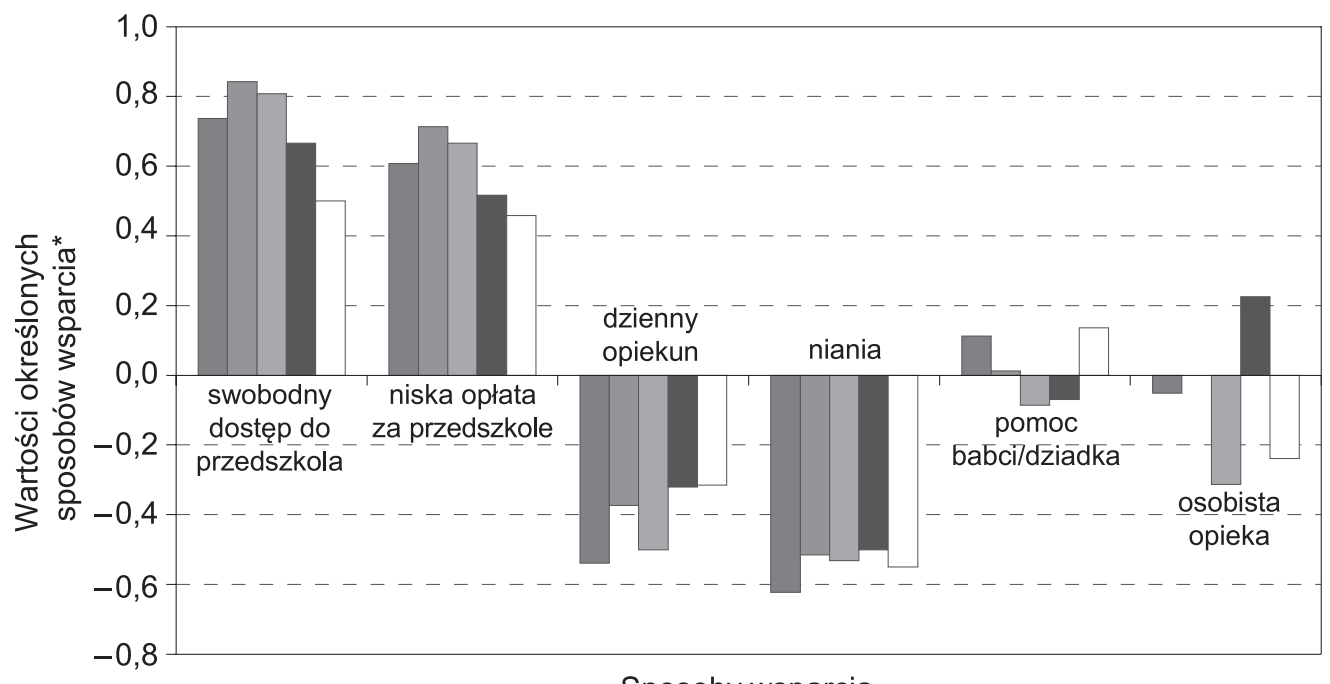

Sposoby wsparcia

$\square$ praca w pełnym wymiarze

$\square$ praca na własny rachunek

$\square$ praca w niepełnym wymiarze $\quad$ praca dorywcza

$\square$ praca w godzinach ponadwymiarowych

Rycina 7. Oczekiwania rodzin odnośnie do sposobów wsparcia w zakresie wychowania przedszkolnego, według statusu na rynku pracy

* im wyższa wartość, tym dana forma wsparcia ważniejsza (skala: od -1 do 1; wartości powyżej 0 ważne, poniżej 0 nieważne).

Źródło: Wyniki badania ankietowego, opracowanie własne.

Analizując relacje pomiędzy dochodami badanych rodzin a postrzeganiem ustawowych i innych rozwiązań w kontekście ich wspierającej funkcji w wychowywaniu dziecka w wieku przedszkolnym (ryc. 8), zauważyć można, że bez względu na dochód najważniejszy jest swobodny dostęp do przedszkola oraz niska opłata za przedszkole. Nieco odmienne są natomiast wskazania badanych rodzin w odniesieniu do pomocy babci/ dziadka oraz osobistej opieki. Te rozwiązania najczęściej wybierali respondenci z dochodem niższym niż $1000 \mathrm{zł}$. Z kolei ankietowani z dochodem powyżej 5000 zł za nieistotną uznali osobistą opiekę. 


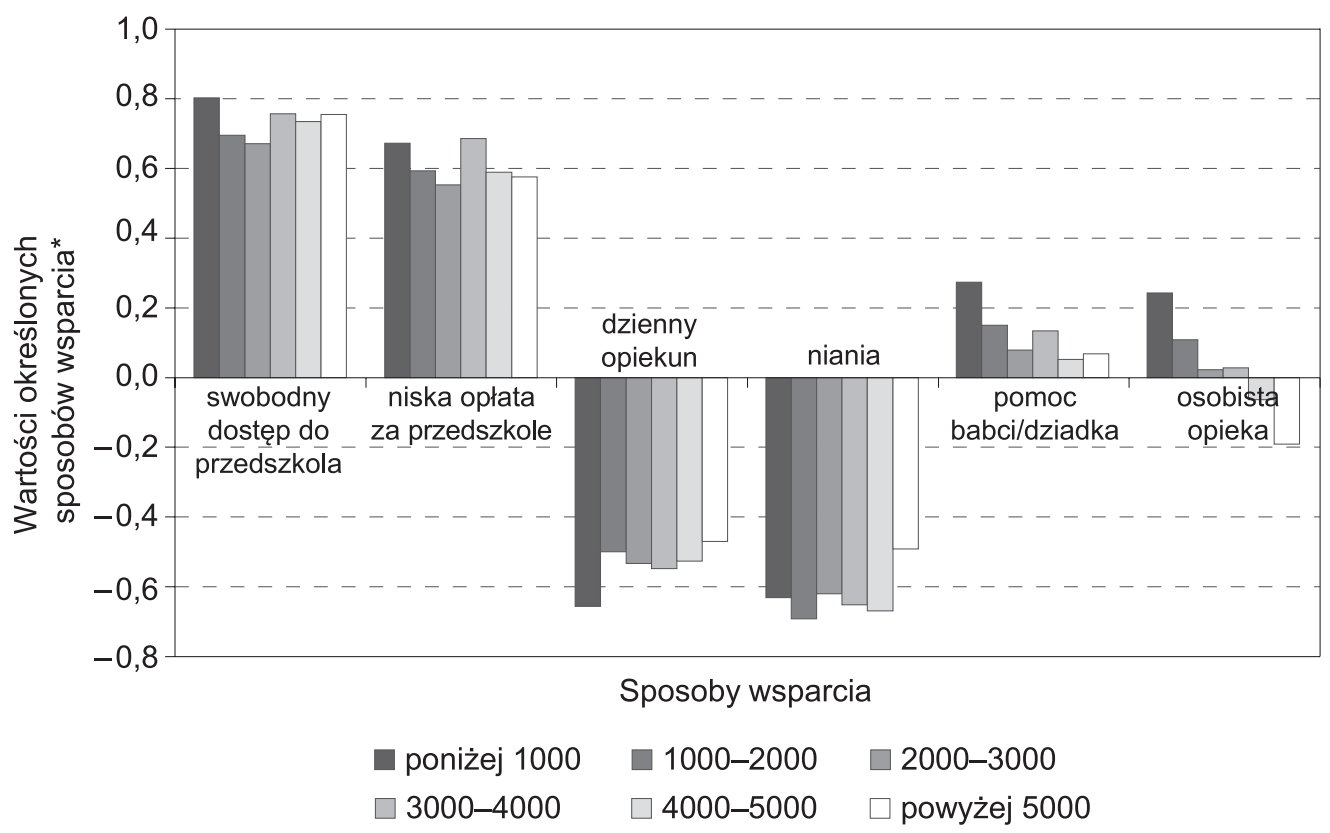

Rycina 8. Oczekiwania rodzin odnośnie do sposobów wsparcia w zakresie wychowania przedszkolnego, według dochodu rodziny

* im wyższa wartość, tym dana forma wsparcia ważniejsza (skala: od -1 do 1; wartości powyżej 0 ważne, poniżej 0 nieważne).

Źródło: Wyniki badania ankietowego, opracowanie własne.

Drugie pytanie ankietowe odnosiło się do zastrzeżeń wobec publicznych przedszkoli i brzmiało: Jakie są Pani/Pana największe zastrzeżenia dotyczące funkcjonowania przedszkola?

Badane rodziny mogły wskazać następujące odpowiedzi (jedną lub więcej): duża odległość dom-praca-przedszkole; dom-przedszkole (konieczność dowożenia); zbyt wysokie opłaty za pobyt dziecka w placówce przedszkolnej; zbyt duża liczba dzieci w grupie; niedogodne godziny funkcjonowania placówki (zbyt późno otwierane i/lub krótko otwarte); brak lub zbyt mało zajęć dodatkowych - w tym miejscu ankietowani mogli podać własne propozycje tego typu zajęć lub też wypowiedzieć się na temat jakości wychowania przedszkolnego w opcji otwartej: inne aspekty.

W świetle opinii badanych rodzin najczęstsze zastrzeżenia dotyczące funkcjonowania publicznych placówek przedszkolnych to: zbyt liczna grupa (54\% odpowiedzi), brak lub zbyt mało zajęć dodatkowych (według 33\% respondentów), duża odległość przedszkola od domu/pracy (26\% wskazań) (ryc. 9). 


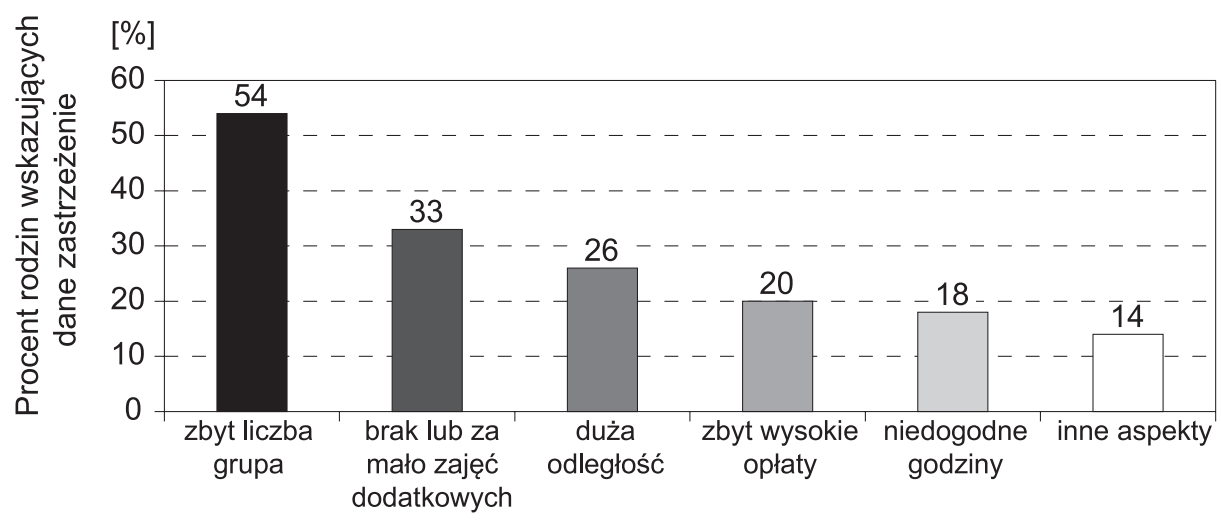

Rodzaje zastrzeżeń

Rycina 9. Zastrzeżenia rodzin dotyczące jakości wychowania przedszkolnego

Źródło: Wyniki badania ankietowego, opracowanie własne.

Pozostałe, rzadziej wskazywane niedogodności, to zbyt wysokie opłaty, niedogodne godziny funkcjonowania placówki oraz inne aspekty (zegzemplifikowane w dalszej części artykułu).

Respondenci, którzy wśród zastrzeżeń dotyczących jakości wychowania przedszkolnego wskazali na brak lub zbyt mało zajęć dodatkowych, mieli możliwość przedstawienia własnych propozycji w tym zakresie (ryc. 10).

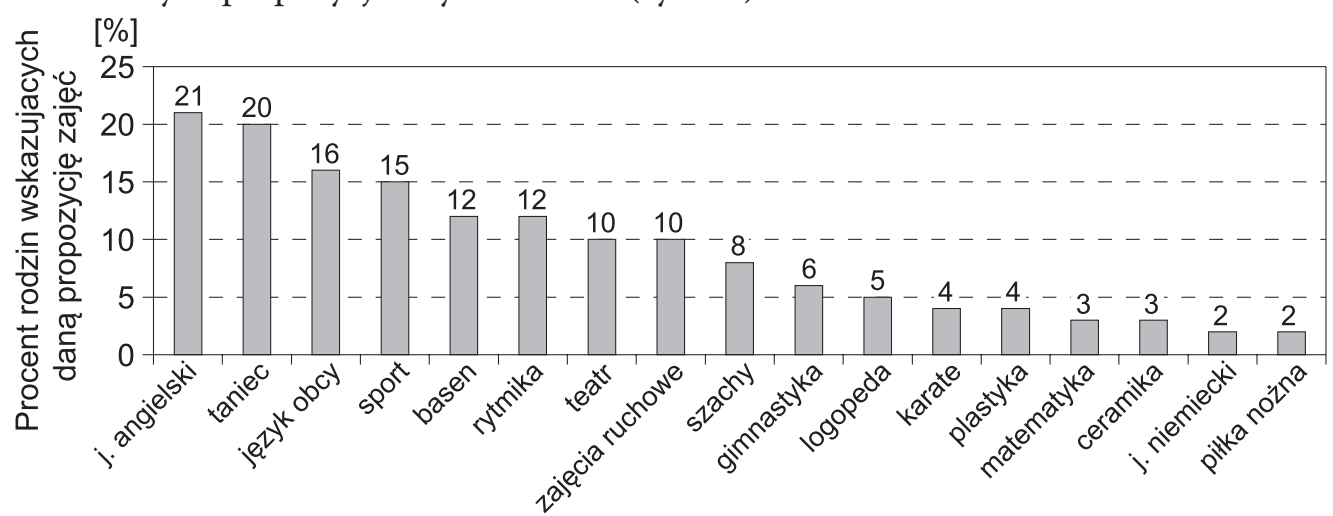

Propozycje określonych zajęć

Rycina 10. Propozycje rodzin dotyczące zajęć dodatkowych w przedszkolu

Źródło: Wyniki badania ankietowego, opracowanie własne.

Z analizy owych propozycji wynikać może, że rodziny w ofercie zajęć dodatkowych oczekują przede wszystkim języków obcych, w tym głównie języka angielskiego. Inne stosunkowo często wskazywane propozycje dodatkowych zajęć to różne formy sportu, 
między innymi taniec i basen, oraz związane z rozwojem muzycznym i artystycznym, na przykład rytmika, zajęcia teatralne. Warto też zaznaczyć, że w większości wypadków respondenci proponowali po kilka form zajęć dodatkowych w tygodniu.

Ciekawe informacje uzyskano też $\mathrm{w}$ analizie wypowiedzi badanych rodzin, dotyczących tzw. innych aspektów (zastrzeżeń) związanych z funkcjonowaniem publicznych placówek przedszkolnych (w pytaniu otwartym). Warte uwagi opinie na ten temat to między innymi: „za mała liczba opiekunów”; „brak swobody wyboru przez rodziców, jakie zajęcia dodatkowe mają mieć dzieci, nawet dodatkowo płatne”; „pobyt dziecka w grupie mieszanej 3,5 i 5 latków”; „zbyt mała kwota dotacji na zajęcia dodatkowe”; „wysokie ceny książek, do zakupu których jesteśmy zmuszani, wywieranie nacisku na uiszczanie dobrowolnej składki na komitet rodzicielski”; „weryfikacja poziomu zajęć dodatkowych”; „bezsensowna rekrutacja: do przedszkola na naszej ulicy chodzą dzieci $\mathrm{z}$ innego osiedla, a my musimy wozić dziecko na inne osiedle, bo w tym nie było już miejsc"; „trudno dostępne miejsca w przedszkolach”; „trudności w uzyskaniu dostępu do przedszkola osób pracujących na umowach o dzieło (artysta)”; „ważna jest dla mnie bliskość przedszkola przy miejscu zatrudnienia”; „brak gabinetów lekarskich, pielęgniarskich i stomatologicznych”; „brak placu zabaw, miejsca do wypoczynku dzieci na dworze”; „brak specjalnego żywienia dla dzieci na dietach”; „wprowadzanie religii już w najmłodszej grupie”; „likwidacja religii w zamian za zajęcia ruchowe” ${ }^{18}$.

\section{Wyniki zogniskowanego wywiadu grupowego}

W celu pogłębienia wiedzy o oczekiwaniach rodzin, dotyczących sposobów wsparcia $\mathrm{w}$ zakresie wychowania przedszkolnego, wynikających z badania ankietowego, przeprowadzony został zogniskowany wywiad grupowy ${ }^{19}$.

Zasadniczą część wywiadu stanowiła dyskusja nad pytaniem, jakie sposoby wsparcia $\mathrm{w}$ zakresie wychowania dziecka w wieku przedszkolnym są najbardziej preferowane. Respondenci mogli odnieść się do dowolnych (niekoniecznie funkcjonujących) instytucji lub usług, które w ich opinii są lub byłyby lepsze od przedszkoli (było to pytanie otwarte). W odpowiedzi uczestnicy badania wskazali przede wszystkim przedszkola. Wychodząc jednak z założenia, że nie znają oni lub nie uprawdopodabniają funkcjonowania innych form omawianego wsparcia, moderator przedstawił hipotetyczną sytuację dostępu do innych form wychowania przedszkolnego, takich jak dzienny opiekun i niania, oraz dokładnie wyjaśnił potencjalne warunki dostępu do nich i sposób funkcjonowania (zakładając, że są one analogiczne do tych dla dzieci w wieku do lat 3, ale adresowane także do dzieci w wieku przedszkolnym, $\mathrm{z}$ odpowiednio dostosowaną do ich wieku podstawą programową zajęć edukacyjnych i wychowawczych). Po porównaniu przez respondentów tych form z przedszkolami publicznymi oraz opieką osobistą lub pomocą babci/

\footnotetext{
18 Więcej: Raport z badań: Diagnoza potrzeb wrocławskich rodzin wobec polityki rodzinnej we Wrocławiu - wychowanie przedszkolne, http://www.frip.org.pl/images/przedszkola.pdf, s. 18-19 (dostęp: 1 lipca 2017).

19 Wywiad trwał około 2 godzin.
} 
dziadka, w tym uszeregowaniu tych wszystkich sposobów wsparcia od najbardziej do najmniej oczekiwanych (analogicznie do badania ankietowego), okazało się, że część badanych rodziców byłaby zainteresowana korzystaniem z usług opieki indywidualnej (zamiast przedszkola). Warunkiem byłoby jednak to, aby usługi te były dostępne tak jak przedszkola (w godzinach od 6.30/7.00 do 17.00) oraz aby obejmowały odpowiednie podstawy programowe, również analogicznie do przedszkolnych.

Opinie badanych o jakości usług w publicznych przedszkolach były podzielone. Część z nich wypowiedziała się pozytywnie, doceniając znaczenie różnorodnych zajęć edukacyjnych czy kontaktów z rówieśnikami (przykładowe wypowiedzi: „Nie miałabym czasu na te wszystkie zajęcia”, „Wielu rzeczy nie potrafiłabym nawet zrobić”, „Nie ma to jak rozwój dziecka w grupie: uczy się, jak współpracować, nawiązywać kontakty, a nawet dyscypliny”, „Prawie codziennie obserwuję, że moje dziecko nauczyło się czegoś nowego”).

Inni uczestnicy wywiadu argumentowali, że osobista opieka jest znacznie lepsza i efektywniejsza niż w placówce przedszkolnej. Były to osoby deklarujące między innymi, że są wykształcone, znają różne języki obce i mają doświadczenie w wychowywaniu dzieci lub też że nie pracują zawodowo, od wielu lat bowiem wychowują małe dzieci i są gotowe na kolejne (przykładowe stwierdzenie: „Uważam, że jako matka jestem w stanie dużo lepiej zająć się swoim dzieckiem niż jakakolwiek instytucja i byłabym na pewno w stanie przygotować je do szkoły nawet lepiej niż przedszkole").

Generalna konkluzja wywiadu, odnosząca się zarówno do przedszkoli publicznych, jak i potencjalnych form wsparcia wychowania przedszkolnego, jest taka, że najważniejsza jest jakość usług świadczonych wobec dzieci, która powinna być systematycznie badana i kontrolowana.

\section{Podsumowanie}

Przedstawione w artykule badania wskazują, że publiczne przedszkola jako najbardziej powszechne instytucje wychowania przedszkolnego są najbardziej pożądaną formą opieki nad dzieckiem w wieku 2,5-5 lat. Argumentów potwierdzających taki stan rzeczy dostarcza przede wszystkim badanie ankietowe, a także, choć niezupełnie, zogniskowany wywiad grupowy wśród rodziców dzieci uczęszczających do publicznych przedszkoli. Niezupełnie, albowiem część uczestników tego wywiadu po zapoznaniu się z potencjalnie dostępnymi usługami, takimi jak dzienny opiekun lub niania, stwierdzili, że byliby - pod pewnymi warunkami - zainteresowani korzystaniem z takich usług zamiast z przedszkoli. Oznacza to, że nie można jednoznacznie odpowiedzieć, twierdząco bądź przecząco, czy badane rodziny oczekują innych niż instytucje przedszkolne form wsparcia w zakresie wychowania przedszkolnego. Brak wskazań na opiekuna dziennego i niani w badaniu ankietowym mógł wynikać z braku odpowiedniej wiedzy o tego typu usługach ( $w$ ankiecie podane zostało jedynie ogólne wyjaśnienie na temat ich ewentualnego funkcjonowania wobec dzieci w wieku przedszkolnym). 
Należy rozważyć poszerzenie i pogłębienie badań na temat oczekiwań rodzin odnośnie do pożądanych form wychowania przedszkolnego, by na tej podstawie rozwijać lokalną politykę na danym obszarze. Ewentualna dywersyfikacja tych form, co warto wziąć pod uwagę, powinna uwzględniać potrzeby rodziców w zależności od liczby dzieci, poziomu wykształcenia, statusu na rynku pracy bądź dochodu. Przedstawione w artykule badanie ankietowe pokazuje, że preferencje rodziców mogą różnić się ze względu na te uwarunkowania. Na przykład respondenci z trojgiem oraz czworgiem i więcej dzieci, $\mathrm{z}$ wykształceniem zasadniczym zawodowym, dochodem poniżej $1000 \mathrm{zl}$ na rodzinę i pracujący dorywczo stosunkowo częściej preferują osobistą opiekę nad dzieckiem niż przedszkole, ale chcieliby za to uzyskiwać świadczenie pieniężne w przeciętnej wysokości około $1430 \mathrm{zł}$ miesięcznie. Obserwacja ta wpisuje się w dyskusje tak w Polsce, jak też w innych krajach, jakie od wielu lat podejmowane są na rzecz uznania osobistego wychowywania dziecka jako pracy w domu, która powinna być odpowiednio wynagradzana, zwłaszcza gdy rodzic nie podejmuje lub rezygnuje $\mathrm{z}$ tego powodu z pracy zawodowej $^{20}$.

Warte podkreślenia wyniki uzyskano też w tej części analizy, w której badane rodziny miały udzielić odpowiedzi, czy chciałyby uzyskiwać comiesięczne świadczenie na każde dziecko bez żadnych dodatkowych warunków oraz - co ciekawsze - na co przeznaczyłyby takie świadczenie. Twierdząco odpowiedzieli prawie wszyscy ankietowani (94\%). Bez względu na dochód w rodzinie oczekiwana wysokość takiego wsparcia wyniosła średnio w granicach około 600-700 zł, a mediana wszystkich wskazań to $500 \mathrm{zł}$ (kwota ta dokładnie odpowiada wysokości świadczenia wychowawczego przyznawanego w ramach Programu Rodzina 500 Plus, który w trakcie realizacji omawianego badania jeszcze nie funkcjonował, ale był już zapowiadany). Im więcej dzieci w rodzinie, tym częściej respondenci deklarowali, że przeznaczyliby te środki na osobistą opiekę.

Ostatnia część omawianych badań dotyczyła jakości usług realizowanych w publicznych przedszkolach. Wynika z nich, iż główne zastrzeżenia i oczekiwania rodzin w tym zakresie występują w następujących kwestiach: liczebność grup (54\% ankietowanych rodzin stwierdziło, że są one zbyt liczne), zajęcia dodatkowe (według $33 \%$ ankietowanych zajęć dodatkowych jest zbyt mało, choć nie zawsze urozmaicona i szeroka oferta zajęć dodatkowych jest pożądana), dostępność miejsc w przedszkolach (ograniczona zwłaszcza w przedszkolach w bliskiej odległości od miejsca zamieszkania lub pracy), odległość przedszkola od miejsca zamieszkania lub pracy (w opinii $26 \%$ ankietowanych rodzin ta jest za duża). Warte uwagi są także oczekiwania rodziców, aby w przedszkolach były gabinety lekarskie albo żeby nie było religii w zakresie zajęć podstawowych (wszak wyznawana wiara i sposób jej praktykowania są w naszym kraju wciąż kwestią wolnego

20 Zob. m.in. I. Błaszczak-Przybycińska, Wartość pracy domowej - wycena empiryczna na podstawie ogólnopolskiego badania budżetu czasu ludności, „Prace Naukowe Uniwersytetu Ekonomicznego we Wrocławiu" nr 364, Wrocław 2014, s. 44-59; S. Siebert, F. Wilson, All work and no pay: consequences of unpaid work in the creative industries, „Work, Employment and Society” 27, z. 4, 2013, s. 711-721; L.Sz. Oláh, M. Gähler, Gender equality perceptions, division of paid and unpaid work, and partnership dissolution in Sweden, „Social Forces" 93, z. 2, 2014, s. 571-594; A. Zachorowska-Mazurkiewicz, Gender, unpaid labour and economics, „Folia Economica” 6, 2016, nr 326, s. 121-132. 
wyboru). Z pewnością $\mathrm{w}$ celu podniesienia jakości wychowania przedszkolnego w publicznych przedszkolach, adekwatnie do potrzeb i oczekiwań rodzin, przydatne byłoby stałe diagnozowanie opinii rodzin na temat funkcjonowania instytucji przedszkolnych oraz - w miarę możliwości - uwzględnianie najczęściej pojawiających się uwag lub postulatów rodziców w rozwoju danych instytucji.

\section{Bibliografia}

Bank Danych Lokalnych GUS, https://bdl.stat.gov.pl.

Barnett W.S., Effectiveness of early educational intervention, „Science” 333(6045), 2011.

Błaszczak-Przybycińska I., Wartość pracy domowej - wycena empiryczna na podstawie ogólnopolskiego badania budżetu czasu ludności, „Prace Naukowe Uniwersytetu Ekonomicznego we Wrocławiu” nr 364, Wrocław 2014.

Families in the economic crisis: Changes in policy measures in the EU, Publications Office of the European Union, Eurofound, Luxembourg 2015, http://www.euro.centre.org/data/1454079403_50470.pdf.

Finansowanie przez gminy przedszkoli publicznych i niepublicznych oraz wykonywanie przez te placówki niektórych zadań w zakresie kształcenia, wychowania i opieki, Raport NIK (LGD-4101-009/2013), Warszawa 2014.

https://www.mpips.gov.pl/praca/strategie-i-dokumenty-programowe/strategia-rozwoju-kapitalu-ludzkiego-srkl---projekt-z-31072012-r/.

Informacja o wynikach kontroli wychowania przedszkolnego. Raport NIK (KNO-4101-01-00/2010), Warszawa 2011, https://www.nik.gov.pl/plik/id,2799,vp,3531.pdf.

Kurowska A., Szczupak K., Zmiany w dostępie do ustug opieki nad dzieckiem poniżej trzech lat w polskich gminach i popyt na te ustugi, „Prace Naukowe Uniwersytetu Ekonomicznego we Wrocławiu” nr 456, Wrocław 2016.

Moroń D., Zmiany w zakresie instytucjonalnej opieki nad dziećmi do lat trzech w Polsce, „Prace Naukowe Uniwersytetu Ekonomicznego we Wrocławiu" nr 239, Wrocław 2011.

Oláh L.Sz., Gähler M., Gender Equality Perceptions, division of paid and unpaid work, and partnership dissolution in Sweden, „Social Forces” 93, 2014, z. 2.

Raport z badań: Diagnoza potrzeb wrocławskich rodzin wobec polityki rodzinnej we Wrocławiu - wychowanie przedszkolne, http://www.frip.org.pl/images/przedszkola.pdf.

Siebert S., Wilson F., All work and no pay: consequences of unpaid work in the creative industries „Work, Employment and Society" 27, 2013, z. 4.

Sprawozdanie z realizacji "Strategii Rozwoju Kapitału Ludzkiego 2020” za 2015 rok, https://www.mpips.gov. $\mathrm{pl} / \mathrm{praca} /$ strategie-i-dokumenty-programowe/strategia-rozwoju-kapitalu-ludzkiego-srkl---projekt-z31072012-r/.

Strategia Rozwoju Kapitału Ludzkiego 2020, s. 70,

Szelewa D., Usługi opiekuńcze dla małych dzieci: główne argumenty za rozszerzeniem dostępu do publicznych usług opieki nad dzieckiem, „Warszawskie Debaty o Polityce Społecznej”, Friedrich-Ebert-Stiftung, ICRA, Warszawa 2011.

Ustawa o opiece nad dzieckiem do lat 3 (Dz.U. z 2016 r. poz. 157 — akt jednolity).

Ustawa o pomocy państwa w wychowywaniu dzieci (Dz.U. z 2016 r. poz. 195).

Ustawa o systemie oświaty (Dz.U. z 2016 r. poz. 1943 — akt jednolity).

Zachorowska-Mazurkiewicz A., Gender, unpaid labour and economics, „Folia Economica” 6, 2016, nr 326. 


\section{Potential directions of changes in the field of the pre-school education in the light of family expectations}

Keywords: institutional and alternative forms of pre-school education, public pre-school institutions, family expectations

Summary

Two research problems have been identified in the article: 1. Do parents of children between 2.5 and 5 years expect other types of pre-school support than pre-school institutions? 2. What are the main concerns and expectations of families regarding the quality of pre-school education in public kindergartens? These problems were the basis for analyzing the potential expectations of families concerning the forms and quality of support in raising preschoolers, based on the opinions of selected groups of Wrocław families (with children attending public kindergartens). This analysis was carried out in Wrocław in the years 2015 and 2016, based on quantitative survey conducted by survey technique and qualitative research - focused group interview. The results of these studies allow us to identify potential activities and directions for changes in pre-school education, which is the main purpose of the article. 